\title{
PERKEMBANGAN DAN GLOBALISASI VIDEO GAME JEPANG
}

\author{
Arsi Widiandari \\ Universitas Diponegoro \\ Email: arsi901@gmail.com
}

\begin{abstract}
Abstrak
Tujuan dari penelitian ini adalah untuk mencari tahu bagaimana permainan video game asal Jepang menjadi sebuah jenis permainan yang mendunia dengan melihat sudut pandang globalisasi. Hal ini dilatarbelakangi oleh pesatnya penerimaan masyarakat dunia terhadap permainan modern tersebut. Meskipun Jepang bukanlah negara yang pertama kali mencetuskan permainan tersebut, akan tetapi pada akhirnya banyak perusahaan asal Jepang yang menguasai sektor ini seperti SONY, NINTENDO dan SEGA, sehingga masyarakat dunia mengakui bahwa Jepang merupakan negara yang mempopulerkan permainan tersebut. Pada penelitian ini, metode yang digunakan adalah dengan metode deskriptif. Penelitian ini membahas mengenai sejarah kemunculan permainan video game asal Jepang serta faktorfaktor yang mempengaruhi popularitas video game asal Jepang. Kesimpulan dari penelitian ini adalah penyebaran dari video game asal Jepang dipengaruhi oleh faktor ekonomi khususnya kemajuan perekonomian Jepang di tahun 1970, diplomasi budaya dan lain-lain.
\end{abstract}

Kata kunci : kebudayaan popular; video game; globalisasi ; permainan modern Jepang

\begin{abstract}
(Title: Development and globalization Japanese Video Game) The purpose of this paper is to find out how Japanese Video Game become worldwide with globalization viewpoint. Many people in the world quickly accepted these video game technology in daily activity. Even tought Japan is not the first country to trigger the game, in the end many Japanese companies have lead this sector for example SONY, NINTENDO and SEGA. The method which used in this paper is descriptive method. The paper shows that Japanese video game popularity influenced by some factor for example Japanese economic progress and globalization. The expansions of Japanese video game has had an influence on economy, cultural diplomacy and others.
\end{abstract}

\section{Keywords : Japanese popular culture; video game; globalization; japanese modern game}

\section{PENDAHULUAN}

Masyarakat dunia telah lama mengenal budaya Jepang khususnya pasca PD II, banyak produk budaya Jepang yang sangat familiar bagi masyarakat dunia, seperti music, film / drama, komik, anime dan juga permainan modern seperti video game. Meskipun dalam perkembangan sejarahnya video game bukan merupakan hasil budaya murni Jepang, akan tetapi masyarakat dunia telah akrab dengan beberapa nama atau perusahaan yang memproduksi video game seperti Nintendo, SEGA dan Sony. Penelitian ini akan meneliti mengenai perkembangan juga globalisasi video game Jepang. 
Dalam penulisan penelitian ini, penulis menggunakan beberapa literatur yang dijadikan sebagai acuan dalam penulisan jurnal ilmiah. Beberapa literatur tersebut di antara lain adalah The Foundation of Geemu yang ditulis oleh Martin Picard. Selain itu, ada pula jurnal ilmiah berjudul Japanese video game in Singapore yang ditulis oleh Wai-ming.

Dalam literatur pertama, Picard banyak memberikan ulasan mengenai sejarah terciptanya video game serta perkembangan meluasnya permainan modern tersebut. Kemudian, pada literatur ke dua, Wai-ming mengulas mengenai kesuksesan video game di pasar ekonomi Singapura. Wai-ming juga membahas mengenai faktor-faktor yang mempengaruhi penerimaan masyarakat Singapore terhadap masuknya video game, di antaranya adalah banyaknya perusahaan video game yang berasal dari Jepang seperti Nintendo, SEGA dan Sony. Hal ini juga didukung oleh banyaknya perusahaan Jepang yang mendirikan kantor cabangnya di Singapura.

Setelah membaca kedua literatur tersebut, penulis melihat bahwa belum ada pembahasan yang dikaitkan dengan globalisasi. Sehingga tujuan dari penelitian ini tidak hanya membahas mengenai perkembangan tetapi juga globalisasi, khususnya dampak yang ditimbulkan dengan semakin meluasnya video game menjadi sesuatu yang semakin global bagi masyarakat dunia.

\section{METODE}

Penelitian ini menggunakan metode pengumpulan data pustaka dengan melakukan analisis data kualitatif yang disajikan dengan narasi kata-kata. Teknik pengumpulan data yang digunakan adalah dengan membaca dan mencatat beberapa jurnal ilmiah, buku teks dan artikel koran.

\section{HASIL DAN PEMBAHASAN}

Kemunculan industri video game dan kesuksesan Jepang dalam menyebarluaskan permainan modern tersebut tak lepas dari sejarah yang panjang. Pada masyarakat tradisional Jepang tentunya permainan jenis ini tidak muncul. Seiring dengan kemajuan perekonomian Jepang khususnya pasca PD II, berkembang pula industri manufaktur yang banyak menyerap tenaga kerja dan semakin meningkatkan perekonomian Jepang. Perkembangan teknologi yang terjadi di Jepang juga turut meningkatkan perkembangan permainan modern dengan kemunculan video game.

Meskipun saat ini perkembangan video game telah melahirkan tipe permainan yang lebih mudah dijinjing, akan tetapi saat mendengar kata video game umumnya orang akan cenderung teringat pada permainan konsol yang digabungkan dengan televisi. Hal ini memang terlihat dari komponen video game yang terdiri dari unsur visual dalam hal ini ditampilkan dengan video dengan alat bantu layar televisi. Sehingga pembahasan mengenai video game tentunya tidak dapat lepas dari unsur kemajuan perekonomian Jepang khususnya di bidang industry manufacturing.

\section{Dari permainan tradisional ke modern}

Sebelum berkembangnya permainan modern yang dipadukan dengan unsur visual/video, masyarakat tradisional Jepang memainkan permainan dengan berbagai rupa dan terkadang terkait dengan alokasi waktu. Sebagai contoh, masyarakat tradisional Jepang seringkali memainkan karuta sejenis permainan kartu pada saat perayaan tahun baru. Hal ini tentu saja berbeda ketika video game digemari oleh masyarakat luas khususnya masyarakat Jepang itu sendiri, dimana permainan 
video game tidak terkait dengan alokasi waktu tertentu. Permainan ini dapat dimainkan setiap waktu. Bagi masyarakat Jepang modern, penggunaan kata geemu ( berasal dari kata game ) memiliki arti sebuah permainan modern yang menggabungkan antara teknologi video, digital dan elektronik. Hal ini tentunya berbeda dengan penggunaan kata asobu yang memiliki arti bermain.

Berbicara mengenai kemunculan dan perkembangan video game, tentunya tidak dapat lepas dari perkembangan industry Jepang itu sendiri. Kemajuan teknologi dan perekonomian Jepang khususnya terjadi pasca PD II. Jepang kemudian menjadi negara di Asia pertama yang secara ekonomi mampu menyamai negara di wilayah Amerika dan Eropa. Puncak perekonomian Jepang itu terjadi sekitar tahun 1970, sekitar 25 tahun sejak kekalahan Jepang di tahun 1945. Perkembangan perekonomian dan industry Jepang dapat terlihat dengan banyaknya pabrik-pabrik atau perusahaan elektronik kelas kakap yang kemudian merajai pasar kebutuhan barang elektronik dunia seperti TV, computer, radio dan lain-lain. Pada perkembangannya, peralatan elektronik tersebut yang kemudian mendukung terciptanya industry video game. Hal ini sesuai dengan pernyataan yang diungkapkan oleh Martin Picard dalam jurnal ilmiahnya yang berjudul "The Foundation of Geemu” yang mengungkapkan bahwa kesuksesan video game Jepang sangat berkaitan erat dengan pesatnya pereonomian Jepang pasca PD II serta hubungan Jepang dengan negara lain khususnya Amerika Serikat.

Video game Jepang merupakan industry yang di dalamnya terdapat beberapa sisi seperti teknologi di bidang eletronik, computer, serta perkembangan teknologi di bidang grafis ( Picard, $2013: 2$ ). Berkaitan dengan berkembangnya industry video game di Jepang, tidak dapat dipungkiri, industry video game Jepang merupakan sebuah inovasi yang dilakukan dengan mengimport teknologi dari Amerika Serikat selama abad 20, yang pada akhirnya dikemas oleh Jepang.

Perkembangan ekonomi Jepang yang meningkat pasca PD II kemudian melahirkan fenomena "leisure boom" ( rejaa buumu ), yang berasal dari konsekuensi berkembangnya industri elektronik rumah tangga seperti televisi dan home entertaintment ( Linhart, 2009 ). Dengan kesuksesan Jepang tersebut, maka muncul inovasi permainan modern yang memiliki ikatan kuat dengan industry elektronik, yaitu video game.

\section{Perkembangan Video Game di Jepang}

Seperti yang telah dijelaskan sebelumnya, popularitas video game muncul sebagai dampak dari kemajuan teknologi khususnya industry elektronik di Jepang itu sendiri. sehingga dapat dikatakan video game Jepang memiliki keterkaitan antara kemajuan ekonomi dan perkembangan budaya Jepang. Kemunculan dan perkembangan industry video game di Jepang tentunya terjadi melalui proses sejarah yang tidak singkat. Dalam subbab ini, akan dibahas sejarah kemunculan industry video game dan perusahaanperusahaan yang memproduksi jenis permainan tersebut.

Pada tahun 1889 ( era Meiji ), Fusajiro Yamauchi mendirikan sebuah perusahaan bernama Marufuku yang pada saat itu memproduksi permainan kartu Jepang yang bernama Hanafuda. Hanafuda sendiri adalah sebuah kartu yang menggunakan motif bunga ( Hana memiliki arti bunga dalam Bahasa Jepang ). Permainan kartu 
ini tidak dapat dimainkan oleh segala golongan usia karena sangat identik dengan permainan judi yang khususnya dimainkan oleh masyarakat Jepang di jaman Feodal ( era Edo atau Tokugawa ). Pada tahun 1907, Marufuku kemudian memproduksi permainan kartu ala barat dan pada tahun 1951 perusahaan tersebut mengubah namanya menjadi Nintendo. Pada masa modern saat ini, kita mengenal Nintendo sebagai salah satu perusahaan Jepang yang sukses melahirkan video game.

Pada tahun 1947, dua tahun pasca PD II, Akio Morita dan Masaharu Ibuka membuka sebuah perusahaan yang bergerak di bidang telekomunikasi yang bernama Tokyo Telecommunications Engineering Company. Morita mendapatkan inspirasi dari sebuah tape recorder buatan Amerika, dan sejak saat itu ia berniat untuk memproduksi barang serupa. Produk transisi yang mereka rancang kemudian mengalami kesuksesan di Jepang, dan pada saat ingin memasarkan ke Eropa dan Amerika, mereka memberikan nama Sony, yang berasal dari kata "Sonus" yang dalam Bahasa Latin memiliki arti suara. Seperti halnya dengan Nintendo, masyarakat saat ini mengenal Sony sebagai salah satu perusahaan yang memproduksi konsol seperti Playstation.

Pada tahun 1954, seorang mantan militer AS pada masa perang Korea, David Rosen melihat popularitas dari sebuah mesin permainan yang menggunakan koin yang berada di sebuah pangkalan militer AS di Jepang. Sekitar tahun 1960an, ia membeli sebuah perusahaan yang memproduksi mesin permainan dan melahirkan nama SEGA yang berasal dari kata "Service Games". SEGA kemudian dikenal sebagai perusahaan video game yang melahirkan sebuah permainan fenomenal dengan tokohnya Sonic.
Di Jepang, meluasnya popularitas video game tidak dapat lepas dari perkembangan ekonomi Jepang sendiri. video game diperkenalkan di acara-acara yang banyak melibatkan masyarakat seperti festival, pameran, gerai di department store dan lain-lain. Selain itu, hubungan baik antara Amerika Serikat dan Jepang juga menjadi penentu kesuksesan video game. Hal ini terlihat pada tahun 1972 saat peluncuran Atari's Pong, video game pertama di AS, dua perusahaan Jepang yaitu Taito dan Sega memproduksi hal serupa di tahun 1973. Pada perkembangannya sejak 1974 , Taito mulai memproduksi dan memasarkan produk mereka ke berbagai negara tak terkecuali AS. Sejak saat itu produk video game asal Jepang menyebar di seluruh masyarakat dunia.

Perubahan teknologi video game kemudian mengalami perubahan mulai dari arcade game hingga permainan home video. Pada awal kemunculannya, teknologi ini muncul dengan permainan arkade, dimana mesinmesin permainan disediakan di sebuah tempat tersendiri seperti bioskop, pusat perbelanjaan dan lain-lain. Pada perkembangannya, muncul video game yang menyajikan permainan yang dapat dimainkan di rumah (home video).

Teknologi ini memungkinkan seseorang memainkan video game tanpa harus keluar rumah. Di dukung dengan kemajuan industry di bidang peralatan elektronik rumah tangga, jenis permainan ini berhasil menjadi salah satu permainan modern yang sangat popular. Dalam hal ini perusahaan Nintendo yang sebelumnya memproduksi permainan kartu judi, kemudian menjadi perusahaan Jepang yang terkenal dengan produksi home video game di tahun 1980an. Permainan home video game yang kemudian terkenal pada saat itu adalah The Mario Brothers, Donkey King. Popularitas Nintendo mencapai puncaknya hingga 
akhir tahun 1980an dan digantikan dengan popularitas SEGA di awal 1990an.

Wai-ming dalam jurnal ilmiahnya yang berjudul Japanese Video Game in Singapore : History, Culture and Industry, mengungkapkan bagaimana industry video game Jepang kemudian mendapatkan tempat di hati warga Singapore. Wai-ming menambahkan bahwa meskipun home video game mendapatkan tempat khusus di hati masyarakat Singapura, akan tetapi hanya segelintir orang yang dapat membeli barang tersebut. Mereka yang dapat membeli, umumnya adalah masyarakat golongan menengah ke atas. Sehingga, kemunculan home video game ini kemudian menumbuhkan aktivitas berkelompok, dimana sekelompok siswa umumnya akan datang berkumpul di rumah salah satu teman yang memiliki home video game.

Sony kemudian merebut pasar dengan meluncurkan konsol Playstation yang menjadi salah satu konsol paling digemari hingga saat ini. Hal ini berkaitan dengan teknologi baik perangkat yakni dengan menggunakan $\mathrm{CD}$ juga peningkatan di kualitas grafis yang digunakan oleh Playstation.

\section{Globalisasi Video Game}

Pasca PD II, Jepang menjadi negara yang cukup menarik perhatian masyarakat dunia lewat keberhasilan di bidang ekonomi dan industry. Hal itu kemudian memicu perkembangan dan penyebaran kebudayaan Jepang ke masyarakat dunia seperti lagu, film, komik dan tak terkecuali video game.

Video game kemudian menyebar luas dan menjadi bagian dari masyarakat global. Globalisasi budaya yang kemudian terjadi tentunya tidak dapat terlepas dari perkembangan ilmu pengetahuan dan teknologi, serta meningkatnya kemudahan informasi.

Kata Globalisasi berasal dari kata "global" yang memiliki makna universal. Sehingga globalisasi kemudian dapat diartikan sebagai sebuah fenomena dimana sesuatu (benda) menjadi milik semua masyarakat global.

Menurut Barker dalam jurnal yang ditulis oleh Suneki (2012), Globalisasi adalah koneksi global ekonomi, social, budaya dan politik yang semakin mengarah ke berbagai arah di seluruh penjuru dunia dan merasuk ke dalam kesadaran kita.

Globalisasi umumnya dimulai dengan adanya perkembangan di bidang teknologi, yang memberikan pengaruh cukup besar terhadap sector lainnya. Dengan semakin berkembangnya teknologi, semakin mudah sebuah informasi disebarkan ke seluruh penjuru dunia. Dalam masyarakat modern saat ini, globalisasi menjadi sesuatu yang tidak dapat dihindarkan.

Perkembangan ilmu pengetahuan dan teknologi yang terjadi di Jepang serta kecepatan Jepang membangun kembali negara pasca PD II menjadikan Jepang memiliki kesempatan untuk menjadikan produk mereka dikenal luas oleh masyarakat global.

Setelah sukses dengan produksi dan penjualan video game di Jepang, video game kemudian juga meluas sampai dengan Asia Tenggara, seperti di Singapura dan Indonesia.

Wai-ming menjelaskan popularitas video game Jepang di Singapura memiliki karakteristiknya tersendiri.

Menurut Wai-ming (2001:151-152), karakteristik tersebut antara lain adalah 
Kiryoku, Volume 3 No 22019

e-ISSN: 2581-0960 p-ISSN: 2599-0497

Tersedia online di http://ejournal.undip.ac.id/index.php/kiryoku

1. Sejak pertama kali datang ke Singapura, video game langsung mendapatkan kesuksesannya dalam waktu yang singkat.

2. Tidak ada kebudayaan Jepang lainnya yang menyaingi kepopularitas video game.

3. Berdasarkan survey yang dilakukan di tahun 1999 lebih dari 60\% remaja Singapura memainkan video game. Mayoritasnya merupakan remaja pria.

4. Industri video game yang berkembang di Singapura dimonopoli oleh perusahaan Jepang.

Menyebarluasnya video game asal Jepang ke seluruh dunia ini semakin menjadikan Jepang semakin dikenal oleh masyarakat global. Jepang tidak hanya dikenal sebagai negara yang sukses di bidang automotive akan tetapi juga pada bidang lain yang bersifat industry kreatif seperti permainan, music dan fashion. Dalam hal ini Jepang telah melakukan globalisasi budaya ke seluruh masyarakat dunia.

\section{SIMPULAN}

Meluasnya penyebaran dan kesuksesan video game Jepang tidak dapat lepas dari kesuksesan industri Jepang khususnya di bidang produksi elektronik rumah tangga. Pada tahun 1970-an, bersamaan dengan puncak perekonomian Jepang pasca PD II, Jepang bekerjasama dengan Amerika Serikat untuk memproduksi video game Atari's Pong. Perusahaan besar seperti Nintendo, SEGA, dan Sony kemudian menjadi beberapa perusahaan asal Jepang yang dikenal dengan produksi konsol video game. Kesuksesan tersebut membuat video game digemari oleh masyarakat dunia. Globalisasi budaya yang berlangsung dengan perantara alat permainan modern tersebut menjadi salah satu modal Jepang untuk menanamkan imej positif mereka di kancah internasional.

\section{DAFTAR PUSTAKA}

Alam, Bachtiar (1998). Globalisasi dan Perubahan Budaya : Perspektif Teori Kebudayaan. Jurnal Antropologi Indonesia

Picard, Martin (2013). The Foundation of Geemu. The International Journal of Computer Game Research. Volume 13 issue 2

Suneki, Sri. (2012) . Dampak Globalisasi Terhadap Eksistensi Budaya Daerah. Jurnal Ilmiah CIVIS, Vol II No 1 Januari

Wai-ming, Benjamin Ng. ( 2001 ). Japanese Video Game in Singapore : History, Culture and Industry. https://www.jstor.org/stable/236539 $\underline{82}$ 